\title{
IMIGRĀCIJAS IETEKME UZ EKONOMIKAS ATTĪSTİBU. KRIEVIJAS FEDERĀCIJAS MARIJELAS REPUBLIKAS UN LATVIJAS GADĪJUMU ANALİZE
}

\author{
Mihails Kozlovs ${ }^{1}$, Jelena Kostromina ${ }^{2}$ \\ ${ }^{1}$ Latvijas Universitātes G̣eogrāfijas un Zemes zinātnu fakultāte, \\ e-pasts: mihails.kozlovs@gmail.com \\ ${ }^{2}$ Krievijas Federācijas Volgas Tehniskās Universitāte, e-pasts; elenakor2004@mail.ru
}

\begin{abstract}
Anotācija. Pētijumā tiek analizēta saikne starp imigrāciju un tautsaimniecības attīstību. Darbā izmantoti Latvijas un Marijelas republikas piemēri. Migrantu ietekme uz ekonomiku tiek vērtēta, izmantojot donorvalstu atribūtus un to iespējamo sasaisti ar ekonomikas rādītājiem aplūkotajos reǵionos.

Lai sagrupētu imigrantu donorvalstis pēc vienotiem kritêrijiem, lietots tautas attīstības indekss, kas bija korigêets, ņemot vērā arī nevienlīdzības faktoru (Inequality Adjusted Human Development Index). Ar šo IAHDI indeksu donorvalstis tika ranžētas atbilstoši ietekmes līmenim uz Marijelas un Latvijas tautsaimniecību. Kopumā donorvalstis tika sagrupētas trijās un četrās grupās un veikta korelācijas analīze, lai izpētītu saikni starp imigrācijas plūsmām un tautsaimniecības attīstību.

Atslēgas vārdi: imigrācija, HDI, IA-HDI, korelācijas analīze, Latvija, Marijelas republika.
\end{abstract}

\section{Ievads}

Imigrācija var būt ḷoti spēcīgs reǵiona vai valsts izaugsmes faktors. Protams, migrācijas procesus ir jāplāno un jāveicina tajā virzienā, kas valstij ir izdevīgs. Reǵionu socioekonomiskājā attīstībā viens no svarīgākajiem elementiem ir inovācijas. To plānošanā, projektēšanā un realizācijā ir jāiesaista augstas kvalifikācijas speciālisti. Lai reǵioni varētu šādus profesionāḷus piesaistīt, ir jāsekmē reǵiona konkurētspēja migrācijas jomā.

Lai reǵionam piesaistītu nepieciešamos migrantus, ir jāattīsta vietējā infrastruktūra, jāsekmē dzīvošanai un pašrealizācijai komfortabli apstākḷi, potenciālajiem darba devējiem jānodrošina iespējas veidot jaunas darba vietas un jāattīsta migrantu atbalsta programmas.

Svarīgi izprast pašlaik esošo situāciju saistībā ar migrācijas procesiem - izzināt migrantu izcelsmes valsts vai reǵiona atribūtus - attīstības līmeni, migrantu izglītības līmeni, kultūras īpatnības, noziedzības līmeni donorvalstīs. Migrācijas ietekme uz 
saṇēmējvalsts ekonomiku un sociālo vidi ir atkarīga no migrantu cilvēkkapitāla izglītības, kvalifikācijas, veselības stāvokḷa un arī sociālām rakstura īpašībām.

Šajā rakstā autori donorvalstis ir ranžējuši pēc vienādiem atribūtiem, un tad nošḳīuši Latvijas un Marijelas republikas tautsaimniecībai izdevīgākas donorvalstis. Tika pierādīts, ka pastāv noteiktas pakāpes sasaiste starp cilvēkkapitālu un ražošanas indeksa svārsībām. Migrantu plūsmas no noteiktām valsts grupām un reǵioniem dod pozitīvu pienesumu tautsaimniecībai kopumā.

\section{Materiāli un metodes}

Pēdējo 5 gadu laikā imigrantu skaits Latvijā ir vismaz dubultojies. Ja 2008. gadā tie bijuši nepilni 5 tūkstoši cilvēku, tad 2014. gadā imigrantu skaits bijis lielāks par 10 tūkstošiem (csb.gov.lv). 56\% no visiem imigrantiem nāk no Eiropas Savienības dalībvalstīm. Trešdaḷa migrantu jeb 34\% nāk no NVS bloka valstīm. Pēdējo 5 gadu laikā straujš imigrantu skaita palielinājums ir vērojams no EEZ zonas valstīm (Norvēǵijas, Islandes, Šveices un Lihtenšteinas).

Krievijas Federācijas Marijelas republikā ikgadējais imigrācijas apjoms svārstās no 5 līdz 8 tūkstošiem cilvēku. Lielākā daḷa - 76\% ir atbraucēji no kaimiṇreǵioniem, $21 \%$ - no NVS un tikai $3 \%$ - no citām valstīm.

Kopējais imigrācijas apjoms liecina tikai par iespējamo iedarbību uz tautsaimniecību. Par šì efekta struktūru un ar̄̄ iedarbības raksturu var spriest, izpētot migrācijas sastāvu. Migrantu ekonomiskā ietekme uz reǵionu attīstību ir atkarīga no donorvalstu sabiedrības atribūtiem. Reǵiona ekonomiskās attīstības sekmēšanai ir svarīgi tādi faktori kā imigrantu izglīitība, kvalifikācija, veselības stāvoklis, prognozējāmais dzīves ilgums, noziedzības līmenis. Visas šīs sabiedrības raksturīpašības veido cilvēkkapitālu, kuru pēc nozīmīguma var iedalīt trijās grupās - negatīvais, neitrālais un pozitīvais. Izvērtējot imigrantu cilvēkkapitālu, var spriest par vinu ietekmes raksturu uz ekonomiku. Lai izvērtētu cilvēkkapitālu, šajā rakstā tika izmantots Tautas attīstības indekss (HDI), kas korig̣ēts, ņemot vērā arī nevienlīdzības faktoru 'IAHDI' (InequalityAdjusted Human Development Index). HDI šajā pētījumā netika izmantots, jo tas iekḷauj arī IKP palielinājumu, kas, savukārt, nenozīmē sabiedrības attīstību, tas var to pat palēnināt (Groningena efekts).

\section{Marijelas gadījums}

N̦emot vērā IAHDI, donorvalstis bija sadalītas trijās grupās:

1. Valstis ar augsto cilvēkkapitālu: Batkrievija, Vācija, Izraēla, Itālija, Kazahstāna, Latvija, Lietuva, Lielbritānija, ASV un Igaunija;

2. Valstis ar vidējo cilvēkkapitālu: Azerbaidžāna, Armēnija, Gruzija un Ukraina;

3. Valstis ar zemu cilvēkkapitālu: Kirgistāna, Moldova, Tadžikistāna un Uzbekistāna.

75\% imigrantu, kas atbrauc uz Marijelas republiku, ir darbspējas vecumā. Šāda vecuma struktūra rada pozitīvu efektu uz tautsaimniecību. Pētījumā uzmanība pievērsta tikai labvēlīgām migrācijas valstīm ar augstu cilvēkkapitālu. Imigrācijas ietekme uz tautsaimniecību tika vērtēta, salīdzinot ekonomiskās izaugsmes un imigrācijas apjoma 
svārstības. Ekonomiskās izaugsmes rādītājs ietver gan ražošanas indeksu, gan jaunu uzṇēmumu veidošanu, gan arī investīciju apjomu IKP.

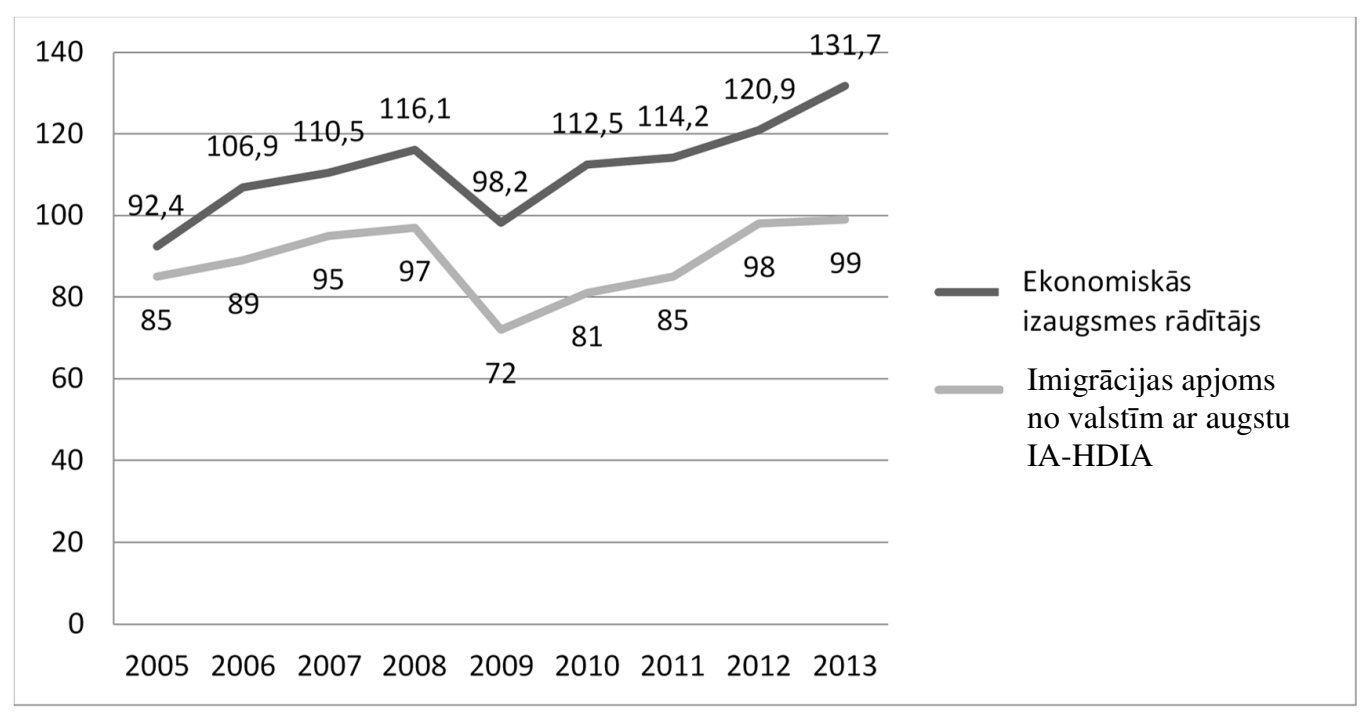

1. attēls. Imigrācijas sasaiste ar Marijelas tautsaimniecību. Avots: Krievijas Federācijas

Centrālā statistikas pārvalde. Autoru apkopojums

Imigrācijas no valstīm ar augstu cilvēkkapitālu ietekme uz ekonomiku Marijelas piemērā ir parādīta 1. attēlā. Korelācijas koeficients starp šiem parametriem ir 0,705 (vidēji stipra atkarība). Visticamāk pastāv pastarpināta imigrācijas ietekme uz ekonomikas izaugsmi.

\section{Latvijas piemērs}

Pēdējo piecu gadu laikā Latvijā ik gadu imigrēja ap 10 tūkstošiem cilvēku. Katru gadu 37-47\% no šiem imigrantiem bijuši Latvijas iedzīvotāji, 30\% Krievijas pilsoņi, tad ukraiņi, baltkrievi, poḷi, lietuvieši (2. attēls).

Vērtējot imigrāciju pēc donorvalstu IA-HDI indeksa, tās varētu sagrupēt trijās kategorijās atkarībā no imigrantu nozīmīguma vietējā ekonomikā. Prioritārās imigrantu donorvalstis būtu Vācija un Izraēla. IA-HDI šajās valstīs ir viens no augstākajiem pasaulē, un imigranti varētu sniegt atbalstu Latvijas tautsaimniecībai. Savukārt, migrācija no Baltkrievijas un Krievijas ir mazāk pievilcīga, bet tomēr IA-HDI indekss Krievijā ir augstāks nekā Latvijā. No Latvijas imigrantu donorvalstīm Ukraina ir vismazāk pievilcīga.

Vērtējot ekonomiskās izaugsmes un migrācijas svārstības no 2006. līdz 2014. gadam, tika secināts, ka pastāv vidēji stipra atkarība starp abiem procesiem. Korelācijas koeficients ir 0,78 . 


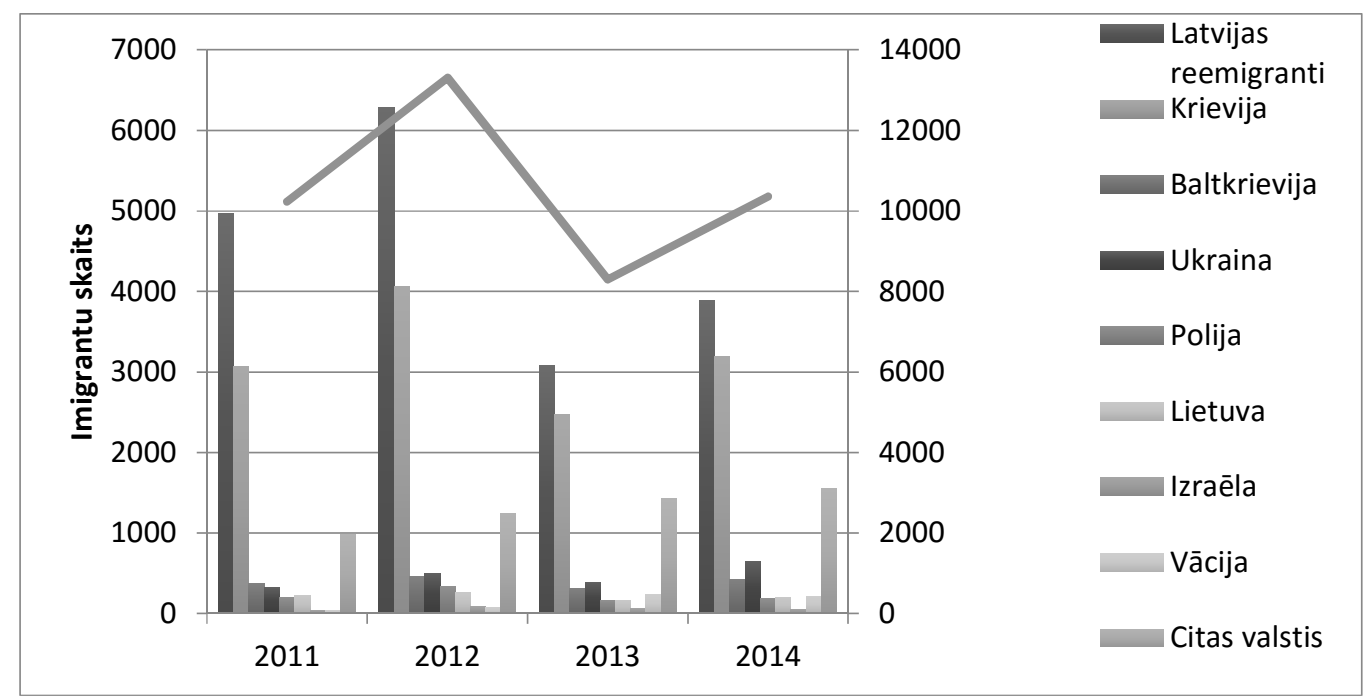

2. attēls. Latvijas imigrantu sadalījums pa izcelsmes valstīm. Avots: Latvijas Centrālā statistikas pārvalde. Autoru apkopojums

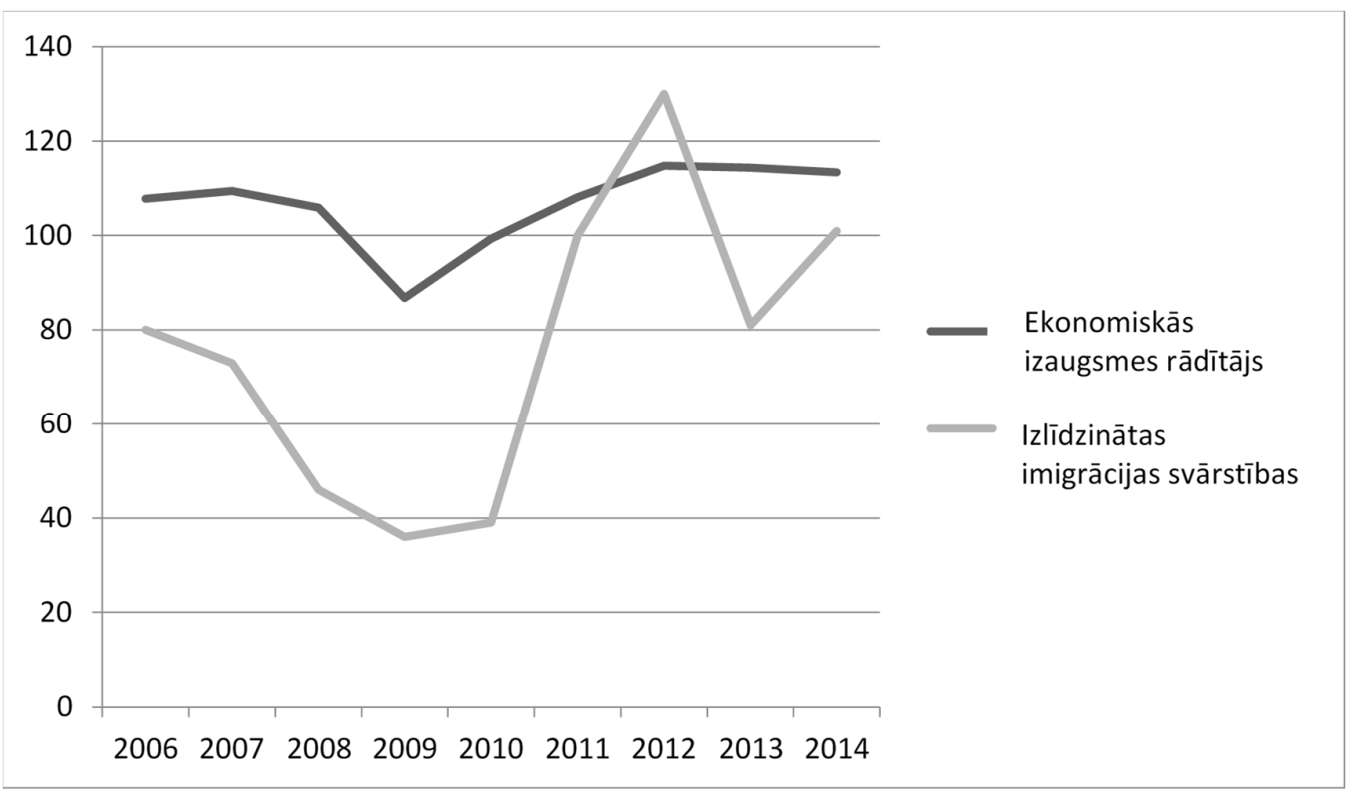

3. attēls. Imigrācijas sasaiste ar Latvijas tautsaimniecību. Avots: Latvijas Centrālā statistikas pārvalde. Autoru apkopojums

\section{Secinājumi}

Izvēlētajos reǵionos (Latvija un Marijelas republika) valstu ar zemu cilvēkkapitālu imigrācijas ekonomiskā ietekme, visticamāk, ir negatīva. Vāja rūpnieciskā sektora attīstība neḷauj efektīvāk izmantot mazkvalificēto darbaspēku.

Imigrācija no valstīm ar augstu cilvēkkapitāla attīstības līmeni sniedz iespēju tautsaimniecības attīstībai, izmantojot imigrantu zināšanas un inovācijas. Korelācijas analīzes rezultāti liecina, ka pastāv saikne starp imigrācijas apjoma svārstībām no IAHDI labvēlīgām valstīm un ekonomikas izaugsmes indeksu. Gan Latvijas, gan Marijelas 
gadījumā korelācija ir pozitīva, un tā liecina par to, ka abām valstīm ir jāsekmē imigrācija no valstīm ar augstu IA-HDI indeksu, kas jau ir imigrantu donorvalstu sarakstā.

\section{Pateicība}

Raksts izstrādāts ar Valsts pētījumu programmas pētnieciskā projekta Nr. 5.2.4. „Sabiedrības atjaunošana, samazinot depopulācijas riskus, veicinot tautas ataudzi un saiknes ar diasporu" atbalstu.

\section{Atsauces}

Hazans, M. (2013). Emigration from Latvia: Recent Trends and Economic Impact. Coping with Emigration in Baltic and East European Countries. Paris: OECD Publishing, 65-110.

King, R., Skeldon, R., Vullnetari, J. (2008). Internal and International Migration: Bridging the Theoretical Divide. Sussex Centre for Migration Research, University of Sussex, UK.

Kozlovs, M. (2014). Comparative analysis of economical migration in Serbia and Latvia in period 2008 till 2013. University of Latvia, 1-69.

Krasnopjorov, O. (2011). Cik cilvēku pameta Latviju un cik vēl pametīs? http://www.makroekonomika.lv/cik-cilveku-latviju-pameta-un-cik-vel-pametis (15.06. 2014)

Skribans, V. (2010). Darbaspēka migrācijas ietekme uz darba tirgu Latvijā. Latvijas Universitātes rakstu krājums: 758 sēj., 189-201.

Бакуменко, Л.П. (2012). Кластеризация регионов Приволжского федерального округа по компонентам качества жизни. Йошкар-Ола: Марийский государственный университет.

Бакуменко, Л.П. (2011). Интегральная оценка качества жизни населения Республики Марий Эл. Вопросы статистики, 6, 60-67.

UNDP (2015). Human development report. New York: PBM Graphics

Latvijas Centrālā statistikas pārvalde. Migrācijas apjomi. http://www.csb.gov.lv (27.02.2016)

Krievijas Federāla statistikas pārvalde. http://maristat.mari.ru (25.02.2016)

\section{Summary}

In this paper, the influence of immigration on the economies of Latvia and the Republic of Mari-El in the Russian Federation is examined. In each of the researched regions, various positive immigration source-countries were identified, and ranged by inequality-adjusted human development index. Then, the correlation between immigration and integral economic development index was studied in both cases. The correlation was found to be positive, and significant enough in order to be taken into account.

In the case of Latvia, it is important to foster immigration flow from existing immigrantsource countries, especially Germany, Israel and Russia. These countries demonstrate better results in the IA-HDI index, and that is why the probability of having a positive effect to the economy is higher than from any other region.

In the case of Republic of Mari-El, 10 attractive immigration source-countries were identified. Taking into consideration immigration trends in Russian regions, it can be observed that a comparatively significant amount of immigrants are coming from CIS countries. Immigration from countries with very high IA-HDI indexes is insignificant. 